\title{
The Effect of Teacher Teaching Skills and Student Interest on History Learning Outcomes
}

\author{
Yadi Sumyadi ${ }^{1,}$, Umasih $^{2}$, Abdul Syukur ${ }^{3}$
}

1,2,3 Program Studi Pasca Sarjana Pendidikan Sejarah, Universitas Negeri Jakarta

A R T I C L E I N F O

Article history:

Received 8 July 2020

Received in revised

Form 01 August 2020

Accepted 18 August

2020

Available online 30

August 2020

Keywords:

Keterampilan Mengajar,

Minat Siswa, Hasil

Belajar is a relationship between teacher teaching skills and student learning outcomes.

\begin{abstract}
A B S T R A C T
Learning outcomes have an important role in the learning process. This is because learning outcomes can be used as a benchmark to determine the extent to which students experience changes after receiving their learning experiences, are observed and measured in the form of knowledge, attitudes and skills. This study aims to analyze teaching skills and teacher learning interest towards historical learning outcomes. The research method used in this research is ex post fact, which means after the fact, by taking survey data. The population and sample in this study were high school students. In the data description analysis stage, the writer describes the problems related to student learning outcomes and the observation data of teacher teaching skills in the learning process. The correlation stage consists of the following steps: analysis prerequisite test and hypothesis testing. Based on the data analysis, the regression equation $Y=44.533+0.506 \times$ was obtained, meaning that each addition of the teacher's teaching skills variable by one unit, the student learning outcomes variable increased by 0.506 units. So, it can be concluded that there
\end{abstract}

\section{Introduction}

History is a subject that emphasizes knowledge and values about the process of change and development of society from past to present. History is an activity carried out by humans in the past (past human effect) which has happened once (einmalig) (Safitri et al., 2018; Tanjung, 2016). History learning has an important role in the development of Indonesian civilization. History learning is a moral education that can make humans wiser and train someone to be skilled as citizens so that they can become human characters as the nation's next generation (Safitri et al., 2018; Tanjung, 2016). History learning does not only talk about years but also must be able to analyze and reconstruct from the information that has been obtained (Erniasih \& Pramono, 2018; Safitri et al., 2018).

Based on the benefits obtained by studying history, history should be a very important subject to study, interesting, fun and not boring. But the reality is not so, history subjects tend to be underestimated and less attractive to students because some of them are boring, history lessons are less interesting, and tend to make students rowdy or sleepy, so history lessons cannot function properly (Erniasih \& Pramono, 2018; Safitri et al., 2018; Tanjung, 2016).

Teachers must know the circumstances and abilities of students, so that teachers can place themselves according to the circumstances of these students in teaching, so that students can receive learning from the teacher properly (Rizki, 2016). Therefore, educators or teachers who become figures and role models for students and their environment must be able to carry out their professional duties, one of which is to have teaching skills. Teaching skills are special abilities that are related to the aspects of implementing learning activities that must be owned and applied by everyone who has a profession as a teacher, tutor, trainer or facilitator in carrying out learning (Sophuan, 2018; Theodora, 2016). Djiwandono (in Atrizka \& Supriyantini, 2018) states that teachers who are skilled in teaching will easily face students who have varied backgrounds and intelligence. Ambarwati (in Yuanita, 2019) states that a teacher must master teaching skills in terms of: (1) strengthening skills, (2) questioning skills, (3) skills using variations, (4) explaining skills, (5) opening and closing lessons skills, (6) ) small group and individual teaching skills, (7) class management skills, and (8) group discussion guiding skills.

Based on the results of observations made, it was found that the factors that caused the low student learning outcomes in history subjects at SMA Perguruan Rakyat 2 Jakarta were suspected to be due to the 
low teaching skills of teachers and interest in learning. The teaching skills of history teachers still have to be considered, sometimes in the history learning process in the classroom the teacher is still the teaching center, the teacher is still the center or central in the learning process so that the tendency of the teacher is still dominant in learning. The teaching skills of teachers are still lacking in using various methods and learning models. Teachers still tend to use the lecture method in providing material. Teachers have not been able to be good tutors and peer guides in group discussions and teachers are still oriented towards books so that they cannot link historical material with daily life, so students tend to be less attentive and easily feel bored, which has an impact on history learning. the results are not optimal and satisfying. For this reason, it is necessary to optimize the teaching skills of teachers in the learning process so that it can foster good interest in learning history so that the results of learning history become better.

Teachers really determine student learning outcomes because teachers are both directors and actors in the learning process which will affect student learning outcomes. In addition, teachers who directly guide, assist, influence, and develop the potential that exist in students achieve goals. This is in accordance with the opinion (Pasaribu, 2015) which states that the teacher is a very important component in the teaching and learning process because the successful implementation of the education process is very dependent on the teacher. Good history teacher teaching skills can encourage students to more easily understand and accept history lessons so that they can develop knowledge and values related to historical events contained in subject matter that are correlated with life today (Erniasih \& Pramono, 2018; Pasaribu, 2015; Safitri et al., 2018).

Research conducted by (Sefani \& Lyna, 2017) states that teacher teaching skills and student learning readiness have direct and indirect effects on learning outcomes through learning motivation. Then the research conducted by (Theodora, 2016) states that there is a significant difference between student learning outcomes taught by teachers with high teaching skills and student learning outcomes taught by teachers with low teaching skills.

Apart from teaching skills, students also need interest in learning. There are several factors that influence learning, one of the factors that need to be considered is student interest in learning (Khaerunnisa et al., 2018). Interest is the presence of curiosity or interest in an idea of thought or event involving attention in which there are strong effective (emotional) elements (Sulistyawati, 2020; Sa'adah et al., 2017; Trisnowali, 2017). Interest can arise from outside or from within. Great interest in something is a large capital means to achieve or obtain the desired goals (Putri \& Isnani, 2019). Students who have a high interest in learning will always pay full attention in their efforts to achieve learning goals (Putri \& Isnani, 2019; Meyanasari \& Widiyanto, 2017). Children who are interested in an activity, wherever they are, will put in four times the effort to learn than children who have little interest or get bored easily (Trisnowali, 2017).

Learning interest has a role in supporting student learning outcomes, students who are not interested in learning materials will show an attitude that is less sympathetic, lazy and not enthusiastic about the teaching and learning process (Meyanasari \& Widiyanto, 2017). If students do not have an effective way of learning, the learning outcomes obtained will be low. To stimulate student attention, each teacher is required to be able to create an atmosphere of the teaching and learning process in such a way as to attract students' attention to what is given. A situation that attracts students' attention is expected to generate student interest and motivation. The better the student's interest in learning, the better the learning outcomes obtained by students, and vice versa (Waluya et al., 2019; Nurtia et al., 2017).

The results of research conducted by (Putri \& Isnani, 2019) states that there is a significant positive influence between interest in learning outcomes and interest is the dominant variable affecting learning outcomes. Then the research conducted by (Waluya et al., 2019) states that students' learning interest has a positive influence on learning outcomes of Islamic economic insert learning in class X IIS economics at MA level in the eastern part of Malang City. Research conducted by (Meyanasari \& Widiyanto, 2017) which states that partially interest in learning affects learning outcomes by $3.42 \%$ and how learning affects learning outcomes by $13.54 \%$ so it can be concluded that interest in learning and learning methods affect learning outcomes of students in class X IPS MAN 1 Magelang City. Then the research conducted by (Nurtia et al., 2017) states that interest in learning has a positive and significant effect on student learning outcomes.

The difference between this study and existing research is 1) Research conducted by (Permatasari \& Palupiningdyah, 2015) examines the effect of student perceptions about teacher teaching skills and student learning facilities on social studies interest, 2) research conducted by (Feriady et al., 2012) examined the effect of teacher teaching skills and the school environment on student interest in learning class XI office administration subject to personnel administration. In this regard, the researcher felt the need to conduct research to see whether there was an effect of teaching skills and teacher learning interest on history learning outcomes at SMA Perguruan Rakyat 2 East Jakarta. 


\section{Methods}

The research method used in this research is ex post fact, which means after the fact, by taking survey data. Ex post facto research is research that aims to find the causes that allow changes in behavior, symptoms or phenomena caused by an event, behavior or things that cause changes in the independent variables that have occurred as a whole (Sukardi, 2004).

The population and sample in this study were students of SMA Perguruan Rakyat 2, East Jakarta. At the data description analysis stage, the author describes the problems related to student learning outcomes and the observation data of teacher teaching skills in the learning process. The correlation stage consists of the following steps: analysis prerequisite test and hypothesis testing.

\section{Result and Discussion}

\section{Instrument analysis}

The instrument used in this study has met the requirements and further analysis on the level of difficulty and distinguishing power of the instrument has met. The relationship and influence test in this study will be tested using SPSS 16.

\section{Description of research results}

The data used in this study are student learning outcomes and data from observations of teacher teaching skills in the learning process. Data on teacher learning outcomes and teaching skills are as follows:

a. Learning Outcomes obtained by an average value (mean) $=82.9091$ and standard deviation (standard deviation) $=5.95742$.

b. Teachers' teaching skills, while the mean value of teacher teaching skills $=86.4545$ and the standard deviation of teacher teaching skills $=6.34608 .3$ ) Hypothesis testing.

Data analysis by calculating the correlation coefficient and the significance test then continued by determining the regression equation, in the calculation of this study using SPSS 16 to determine the relationship between creative thinking skills and student learning outcomes and the effect of creative thinking skills on student learning outcomes.

Table 1. Test data validity of teacher teaching skills and learning outcomes.

\begin{tabular}{lcc}
\hline & Teachers' teaching skills & Learning Outcomes \\
\hline Teachers' teaching skills & 1 & 475 \\
$\mathrm{~N}$ & 26 & 140 \\
& & 26 \\
Learning Outcomes & 475 & 1 \\
$\mathrm{~N}$ & 140 & 26 \\
& 26 & 26 \\
\hline
\end{tabular}

\section{The correlation results are significant}

Hypothesis

H0: There is a relationship between teacher teaching skills and student learning outcomes.

Ha: There is no relationship between teacher teaching skills and learning outcomes.

Basis for decision making: If probability $>0.05$ then $\mathrm{HO}$ is accepted, if probability $<0.05$ then H0 is rejected, it is obtained $=0.140>0.05$ so that $\mathrm{HO}$ is accepted. So, there is a relationship between teacher teaching skills and student learning outcomes.

Conclusion: The correlation coefficient is significant, that is, it can be generalized to all samples taken.

Table 2. Test of the Effect of the Ability of Teacher Teaching Skills on Learning Outcomes.

\begin{tabular}{|c|c|c|c|c|c|}
\hline Model & nonstan & std. Error & $\begin{array}{c}\text { Standard } \\
\text { Beta }\end{array}$ & $\mathbf{t}$ & sig \\
\hline Constant & 44.533 & 25.972 & & 1.715 & 0,121 \\
\hline Teacher teaching skills & .506 & 0,313 & 0,475 & 1.618 & 0,140 \\
\hline
\end{tabular}


The table above shows the regression equation for the variable teaching skills of teachers and student learning outcomes. Obtained regression equation $\mathrm{Y}=44.533+0.506 \mathrm{x}$, meaning that each addition of the teacher's teaching skills variable by one unit, the student learning outcomes variable increases by 0.506 units.

\section{Discussion}

The correlation coefficient was found to be significant, that is, it can be generalized to all samples taken. So, it can be said that there is an influence between teacher teaching skills on student learning outcomes. This shows that the level of teacher teaching skills will have an impact on the differences in the achievement of learning outcomes obtained at school. These results prove the relevance of the theory put forward by (Uno, 2009) which states that basically behavior changes that can be demonstrated by students must be influenced by the educational background and experience a teacher has. Therefore, the higher the level of teacher teaching skills will also affect the learning outcomes obtained by students.

Teachers must know the circumstances and abilities of students, so that teachers can place themselves according to the circumstances of these students in teaching, so that students can receive learning from the teacher properly (Rizki, 2016). Therefore, educators or teachers who become figures and role models for students and their environment must be able to carry out their professional duties, one of which is to have teaching skills. Teaching skills are special abilities that are related to the aspects of implementing learning activities that must be owned and applied by everyone who has a profession as a teacher, tutor, trainer or facilitator in carrying out learning (Sophuan, 2018; Theodora, 2016). Djiwandono (in Atrizka \& Supriyantini, 2018) menyatakan bahwa guru yang terampil mengajar akan dengan mudah menghadapi siswa yang mempunyai latar belakang dan kecerdasan yang bervariasi. Ambarwati (in Yuanita, 2019) states that teachers who are skilled in teaching will easily face students who have varied backgrounds and intelligence. Ambarwati (in Yuanita, 2019) states that a teacher must master teaching skills in terms of: (1) strengthening skills, (2) questioning skills, (3) skills using variations, (4) explaining skills, (5) opening and closing lessons skills, (6) ) small group and individual teaching skills, (7) class management skills, and (8) group discussion guiding skills

Teachers must have good competence and character as basic assets to become an educator, as well as prospective teachers who will become teachers so that they can carry out their duties professionally (Yuanita, 2019). The teacher before carrying out learning must prepare the lesson material or material that will be given to students or things that must be prepared before starting learning (Hermawan, 2017). Teachers' skills, professionalism, and performance greatly influence student learning outcomes (Samrin, 2014). A teacher must also have teaching skills. Basically, teaching skills are special abilities with regard to the aspects of implementing learning activities that must be owned and applied by everyone who has a profession as a teacher, tutor, trainer or facilitator in carrying out learning (Sophuan, 2018; Theodora, 2016).

Research conducted by (Sefani \& Lyna, 2017) states that teacher teaching skills and student learning readiness have direct and indirect effects on learning outcomes through learning motivation. Then the research conducted by (Theodora, 2016) states that there is a significant difference between student learning outcomes taught by teachers with high teaching skills and student learning outcomes taught by teachers with low teaching skills.

Apart from teaching skills, students also need interest in learning. There are several factors that influence learning, one of the factors that need to be considered is student interest in learning (Khaerunnisa et al., 2018). Interest is the presence of curiosity or interest in an idea of thought or event involving attention in which there are strong effective (emotional) elements ( Sulistyawati, 2020; Sa'adah et al., 2017; Trisnowali, 2017). Interest can arise from outside or from within. Great interest in something is a large capital means to achieve or obtain the desired goals (Putri \& Isnani, 2019). Students who have a high interest in learning will always pay full attention in their efforts to achieve learning goals (Putri \& Isnani, 2019; Meyanasari \& Widiyanto, 2017). Children who are interested in an activity, wherever they are, will put in four times the effort to learn than children who have little interest or get bored easily (Trisnowali, 2017).

Learning interest has a role in supporting student learning outcomes, students who are not interested in learning materials will show an attitude that is less sympathetic, lazy and not enthusiastic about the teaching and learning process (Meyanasari \& Widiyanto, 2017). If students do not have an effective way of learning, the learning outcomes obtained will be low. To stimulate student attention, each teacher is required to be able to create an atmosphere of the teaching and learning process in such a way as to attract students' attention to what is given. A situation that attracts students' attention is expected to generate student interest and motivation. The better the student's interest in learning, the better the learning outcomes obtained by students, and vice versa (Waluya et al., 2019; Nurtia et al., 2017). 
The results of research conducted by (Putri \& Isnani, 2019) states that there is a significant positive influence between interest in learning outcomes and interest is the dominant variable affecting learning outcomes. Then the research conducted by (Waluya et al., 2019) states that students' learning interest has a positive influence on learning outcomes of Islamic economic insert learning in class X IIS economics at MA level in the eastern part of Malang City. Research conducted by (Meyanasari \& Widiyanto, 2017) which states that partially interest in learning affects learning outcomes by $3.42 \%$ and how learning affects learning outcomes by $13.54 \%$ so it can be concluded that interest in learning and learning methods affect learning outcomes of students in class X IPS MAN 1 Magelang City. Then the research conducted by (Nurtia et al., 2017) states that interest in learning has a positive and significant effect on student learning outcomes.

\section{Conclusion}

Teachers must know the circumstances and abilities of students, so that teachers can place themselves according to the circumstances of these students in teaching, so that students can receive learning from the teacher properly (Rizki, 2016). Therefore, educators or teachers who become figures and role models for students and their environment must be able to carry out their professional duties, one of which is to have teaching skills. Apart from teaching skills, students also need interest in learning. Interest is the existence of curiosity or interest in a thought or event that involves attention (Sulistyawati, 2020; Sa'adah et al., 2017). Learning interest has a role in supporting student learning outcomes, students who are not interested in learning materials will show an attitude that is less sympathetic, lazy and not enthusiastic about the teaching and learning process. If students do not have an effective way of learning, the learning outcomes obtained will be low. Based on the results and discussion, it can be concluded that there is a relationship between teacher teaching skills and student learning outcomes.

\section{References}

Atrizka, D., \& Supriyantini, S. (2018). Differences in Teaching Skills in Terms of Classroom Leadership Style in Teachers SMAN 11 Medan. Jurnal Diversita, 4(1). https://doi.org/https://doi.org/10.31289/diversita.v4i1.1598

Erniasih, U., \& Pramono, S. E. (2018). Perbedaan Hasil Belajar dengan Menggunakan Media Video Edukasi dan Media Video Dokumenter pada Pembelajaran Sejarah di SMA N 12 Semarang Tahun Ajaran 2017/2018. Indonesian Journal of History Education, 6(2), 162-171. https://journal.unnes.ac.id/sju/index.php/ijhe/article/view/27646

Feriady, M., Harnanik, H., \& Sunarto, S. (2012). Pengaruh Persepsi Siwa Tentang Keterampilan Mengajar Guru Dan Fasilitas Belajar Siswa Terhadap Minat Belajar IPS Kelas VIII SMP N 3 Purbalingga. $\begin{array}{llll}\text { Economic Education } & \text { Analysis }\end{array}$ http://journal.unnes.ac.id/sju/index.php/eeaj/article/view/544

Hermawan, R. (2017). IMPLEMENTASI KURIKULUM 2013 DAN KINERJA GURU TERHADAP KUALITAS HASIL BELAJAR PENDIDIKAN JASMANI. JUARA: Jurnal Olahraga, 2(1). https://doi.org/https://doi.org/10.33222/juara.v2i1.31

Khaerunnisa, F., Sunarjan, Y., \& Atmaja, H. T. (2018). Pengaruh Penggunaan Media Power Point Terhadap Minat Belajar Sejarah Siswa Kelas X SMA Negeri 1 Bumiayu Tahun Ajaran 2017/2018. Indonesian $\begin{array}{llll}\text { Journal of History 31-41. } & \text { Education, }\end{array}$ https://doaj.org/article/6c39cc0aa5974cdfb76bb917f1f14a99

Meyanasari, S., \& Widiyanto, W. (2017). Pengaruh Minat Dan Cara Belajar Terhadap Hasil Belajar Mata Pelajaran Ekonomi Siswa Kelas X Ips Man 1 Kota Magelang Tahun Ajaran 2015/2016. Economic Education Analysis Journal, https://doi.org/https://journal.unnes.ac.id/sju/index.php/eeaj/article/view/16448

Nurtia, W., Ramayani, Ci., \& Sumarni, S. (2017). Pengaruh Disiplin Belajar Siswa Fasilitas Belajar Di Sekolah Dan Minat Belajar Terhadap Hasil Belajar IPS Siswa Kelas VIII SMP N 4 Sutera. Journal of Economic and Economic 209-216. https://doi.org/10.22202/economica.2017.v5.i2.414

Pasaribu, E. (2015). Meningkatkan Hasil Belajar dengan Metode Contextual Teaching Learning pada Mata Pelajaran Sejarah. Jurnal Pendidikan Ilmu-IImu Sosial, 7(1), 13-19. 
https://doi.org/https://doi.org/10.24114/jupiis.v7i1.2269

Permatasari, E., \& Palupiningdyah, P. (2015). Pengaruh Keterampilan Mengajar Guru Dan Lingkungan Sekolah Terhadap Minat Belajar Siswa Kelas XI Administrasi Perkantoran Mapel Administrasi Kepegawaian Di SMK N 1 Slawi. Economic Education Analysis Journal, 4(3). http://journal.unnes.ac.id/sju/index.php/eeaj/article/view/8622

Putri, D. T. N., \& Isnani, G. (2019). Pengaruh Minat Dan Motivasi Terhadap Hasil Belajar Pada Mata Pelajaran Pengantar Administrasi Perkantoran. Journal of Medives : Journal of Mathematics Education IKIP Veteran Semarang, 3(2). https://doi.org/https://doi.org/10.31331/medivesveteran.v3i2.748

Rizki, M. Y. (2016). Peningkatan Keterampilan Memberi Umpan Balik Guru Pendidikan Jasmani dan Kesehatan Kecamatan Taman Kabupaten Sidoarjo. Jurnal SPORTIF : Jurnal Penelitian Pembelajaran, 2(1), 72. https://doi.org/10.29407/js_unpgri.v2i1.658

Sa'adah, I., Prmono, S. E., \& Suharso, R. (2017). Pengembangan media video motion graphic sejarah pemerintahan Herman Willem Daendels (1808-1811) dalam pembelajaran sejarah Indoneia untuk meningkatkan minat belajar siswa untuk SMA. Indonesian Journal of History Education, 5(1), 25-31.

Safitri, N., Utomo, C. B., \& Amin, S. (2018). Pemanfaatan Situs Purbakala Semedo Sebagai Sumber Belajar Sejarah Bagi Siswa Kelas X IPS SMA Negeri 1 Dukuhwaru dan SMA Negeri 3 Slawi Kabupaten Tegal Tahun Pelajaran 2017/2018. Indonesian Journal of History Education, 6(2), 172-183. https://journal.unnes.ac.id/sju/index.php/ijhe/article/view/27647

Samrin, S. (2014). Pengaruh Profesionalisme Guru dan Kinerja Guru Terhadap Prestasi Belajar Pendidikan Agama Islam Siswa MAS Al-Irsyad Kecamatan Lalonggasumeeto Kabupaten Konawe. AL-IZZAH: Jurnal Hasil-Hasil Penelitian, 9(2). https://doi.org/http://dx.doi.org/10.31332/ai.v9i2.162

Sefani, S., \& Lyna, L. (2017). Pengaruh Keterampilan Mengajar Guru Dan Kesiapan Belajar Terhadap Hasil Belajar Ekonomi Melalui Motivasi Belajar Sebagai Variabel Intervening Siswa Kelas XI IS Sma Negeri 14 Semarang. Economic Education Analysis Journal, 6(1). http://journal.unnes.ac.id/sju/index.php/eeaj/article/view/13471

Sophuan, S. (2018). Peningkatkan Keterampilan Mengajar Guru SMP mata Pelajaran IPA Dalam Menerapkan Pendekatan Saintifik. Tadrib: Jurnal Pendidikan Agama Islam, 4(2), 335-355. https://doi.org/10.19109/tadrib.v4i2.2860

Sukardi (2004). Metodologi Penelitian Pendidikan. Jakarta: Bumi Aksara

Sulistyawati, E. (2020). Keefektifan pendekatan kontekstual berbasis budaya lokal ditinjau dari prestasi, minat belajar , dan apresiasi terhadap matematika. 6(1), 27-42. https://doi.org/https://doi.org/10.37058/jp3m.v6i1.1421

Tanjung, S. (2016). Pengaruh Media Pembelajaran Dan Gaya Kognitif Terhadap Hasil Belajar Sejarah. Paramita: Historical Studies Journal, 25(2), 261. https://doi.org/10.15294/paramita.v25i2.5170

Theodora, B. D. (2016). Pengaruh Keterampilan Mengajar Guru Terhadap Hasil Belajar Siswa Sma Se-Kota Malang Yang Di Kontrol Dengan Variasi Sumber Belajar. Journal of Accounting and Business Education, 2(4). https://doi.org/10.26675/jabe.v2i4.6079

Trisnowali, A. (2017). Pengaruh Motivasi Berprestasi, Minat Belajar Matematika, Dan Sikap Belajar Matematika Terhadap Hasil Belajar Matematika Pada Siswa Sman 2 Watampone. MaPan, 5(2), 259278. https://doi.org/10.24252/mapan.v5n2a8

Uno, H.B. 2009. Profesi Kependidikan. Jakarta:PT.Bumi Aksara

Waluya, E. B., Hakim, L., \& Sakti, N. C. (2019). Pengaruh Minat dan Motivasi Terhadap Hasil Belajar Insert Ekonomi Syariah dengan Intervening Kecerdasan Spiritual Pada Mata Pelajaran Ekonomi di Madrasah Aliyah Kota Malang. Jurnal Penelitian, 13(2). https://doi.org/http://dx.doi.org/10.21043/jp.v13i2.6001

Yuanita, Y. (2019). Tingkat Keterampilan Dasar Mengajar Calon Guru Sekolah Dasar Pada Perkuliahan Mikroteaching [Level of Basic Skills for Teaching Prospective Primary School Teachers at Mikroteaching Lectures]. PEDAGOGIA: Jurnal Pendidikan, 8(1). https://doi.org/10.21070/pedagogia.v8i1.1952 